\title{
Serum Human Epididymis Protein 4 is a Potential Biomarker for Early Chronic Kidney Disease in an Obese Population [Retraction]
}

Tan S, Zeng Y, Kuang S, Li J. Diabetes Metab Syndr Obes. 2021;14:1601-1608.

The Editor and Publisher of Diabetes, Metabolic Syndrome and Obesity: Targets and Therapy wish to retract the published article. Concerns were raised over a discrepancy in the ethics statement and patient cohort location reported in the article. The ethics committee who approved the study was reported as the Ethics Committee of Renmin Hospital of Weihai Central Hospital and the location of the patient cohort was described as Weihai Central Hospital. These were not the same as the Second Affiliated Hospital of the University of South China from which the authors were affiliated.

The authors explained an error had been made and the Ethics Committee of the Second Affiliated Hospital of the
University of South China approved the study and the cohort consisted of patients from the Second Affiliated Hospital of the University of South China. However, the authors were unable to provide a satisfactory explanation for why the misreporting had occurred and could not provide the original ethical review documents from the Ethics Committee of the Second Affiliated Hospital of the University of South China.

Our decision-making was informed by our policy on publishing ethics and integrity and the COPE guidelines on retraction.

The retracted article will remain online to maintain the scholarly record, but it will be digitally watermarked on each page as "Retracted".

\section{Publish your work in this journal}

Diabetes, Metabolic Syndrome and Obesity: Targets and Therapy is an international, peer-reviewed open-access journal committed to the rapid publication of the latest laboratory and clinical findings in the fields of diabetes, metabolic syndrome and obesity research. Original research, review, case reports, hypothesis formation, expert opinion and commentaries are all considered for publication. The manuscript management system is completely online and includes a very quick and fair peer-review system, which is all easy to use. Visit http://www.dovepress.com/testimonials.php to read real quotes from published authors. 